\title{
Analisa Kualitas Pelayanan, Kepercayaan dan Keamanan Terhadap Tindakan Pembelian Produk Secara Online
}

\author{
Indah Handaruwati \\ Program Studi Manajemen, Fakultas Ekonomi, Universitas Kristen Surakarta- Indonesia \\ indahhandaruwati80@gmail.com
}

\begin{abstract}
This study will examine the Analysis of Service Quality, Trust and Safety of Online Purchasing Actions. The purpose of this research is to find out how far the role of service quality, trust and security will be in online purchasing and to provide an overview of consumer behavior when considering making a purchase. This study uses a questionnaire as a research instrument to obtain data from consumers who make online purchases with a total sample of 30 people. The analysis tool that will be used is Multiple Linear Regression to test the effect of the independent variable on the dependent variable. The results of the multiple linear regression equation are obtained $Y=$ $0.256 X_{\_} 1+0.613 X \_2+0.115 X \_3+e$ Based on the regression equation, the variables of Service Quality, Trust and Safety all have an influence on Online Purchasing Actions. Results of the F-test. From testing using the F test, it was found 76.513. This figure means that the effect of Service Quality, Trust and Security on Online Purchasing Actions is 76,513. Meanwhile, from the results of the t test there is a relationship between service quality factors of 4,657, security of 6,628, and trust of 4,751. Of the three factors, the security factor is the dominant influence.
\end{abstract}

Keywords- Quality of service, Trust, Security and Online Purchasing Actions

\begin{abstract}
Abstrak- Penelitian ini akan meneliti tentang Analisa Kualitas Pelayanan, Kepercayaan dan Keamanan Terhadap Tindakan Pembelian secara online. Tujuan Penelitian ini untuk mengetahui seberapa jauh peranan kualitas pelayanan, kepercayaan dan keamanan terhadap tindakan pembelian online serta memberikan gambaran perilaku konsumen pada saat akan mempertimbangkan untuk melakukan pembelian. Penelitian ini menggunakan kuesioner sebagai instrumen penelitian untuk mendapatkan data dari konsumen yang melakukan tindakan pembelian secara online dengan jumlah sampel sebanyak 30 orang. Alat analisis yang akan digunakan adalah Regresi Linear Berganda untuk menguji pengaruh variabel independen terhadap variabel dependen. Hasil persamaan regresi linear berganda diperoleh $Y=0.256 X \_1+0.613 X \_2+0.115 X \_3+e$ Berdasarkan persamaan regresi tersebut variabel Kualitas pelayanan, Kepercayaan dan Keamanan semuanya mempunyai pengaruh Terhadap Tindakan Pembelian Secara Online. Hasil F-test Dari pengujian menggunakan uji $F$ didapatkan angka 76.513. Angka tersebut mempunyai maksud bahwa pengaruh Kualitas pelayanan, Kepercayaan dan Keamanan terhadap Tindakan Pembelian Online adalah 76.513. Sedangkan dari hasil uji t terdapat hubungan antara faktor Kualitas pelayanan sebesar 4.657, Keamanan sebesar 6.628, dan Kepercayaan sebesar 4.751. Dari ke tiga faktor tersebut faktor Keamanan adalah yang dominan pengaruhnya.
\end{abstract}

Kata Kunci- Kualitas layanan, Kepercayaan, Keamanan dan Tindakan Pembelian Online

\section{PENDAHULUAN}

Salah satu media informasi yang berkembang dengan cepat saat ini adalah internet. Perkembangan internet yang semakin pesat berdampak pada kegiatan bisnis yaitu dengan adanya bisnis online. Bisnis online pada mulanya hanya melakukan penjualan buku, majalah, kaset dan piringan (LaQuey, 1997). Bisnis online merupakan kegiatan electronic commerce (ecommerce) dimana aktifitas menjual dan membeli produk atau jasa melalui internet (Hausman dan Siekpe, 2009). Indonesia pada Juni 2012 menduduki peringkat keempat untuk jumlah pengguna internet di kawasan Asia. Jumlah pengguna internet di Indonesia sebanyak 55 juta dan 51 juta diantaranya memiliki akun facebook (www.internetworldstats.com). Jumlah pengguna internet di Indonesia yang terus meningkat didorong popularitas facebook menjadikan masyarakat tidak lagi menganggap internet hanya digunakan untuk kegiatan intelektual, namun lebih dari itu internet digunakan untuk membuat jejaring sosial. Kondisi tersebut memberikan peluang besar e commerce untuk semakin tumbuh berkembang di Indonesia (Sulianta, 2012). Tingkat kesadaran masyarakat Indonesia terhadap e-commerce turut menumbuhkan penjualan online melalui media sosial (Rosalina, 2013). Sosial media telah mengalami perkembangan dalam hal fungsi, dimana sekarang sosial media yang sering dikunjungi bukan hanya dijadikan untuk berinteraksi semata atau berkirim kata lewat pesan akan tetapi sekarang media sosial telah dimanfaatkan lebih maju untuk dapat melakukan bisnis jual beli. Salah satunya pemanfaatan jejaring sosial facebook, yang hadir sebagai situs komunikasi sosial terbesar di dunia. Selain dapat berinteraksi, facebook banyak 
dimanfaatkan untuk melakukan pemasaran seperti penjualan baju, buku, tiket pesawat, dan aksesoris lainnya. Belanja melalui facebook secara online sangatlah mudah. Hanya dengan memiliki account facebook sudah bisa menikmati belanja secara online dengan harga yang sangat terjangkau. Perusahaan menggunakan internet untuk memberikan informasi pada konsumen dan rekan kerjanya secara langsung tanpa melalui perantara [1]. Terdapat banyak faktor yang menyebabkan seseorang untuk berbelanja online di situs Internet. Mulai dari biaya yang murah, kualitas jenis barang, kepercayaan, fasilitas kemudahan transaksi, sampai dengan beberapa faktor lainnya [2].

Menurut Geffen (2002) faktor yang sangat penting yang bisa mempengaruhi minat pembelian online adalah faktor kepercayaan. Faktor kepercayaan menjadi faktor kunci dalam setiap jual beli secara online. Hanya pelanggan yang memiliki kepercayaan dan beranilah yang akan melakukan transaksi melalui media internet. Karena itu jika tidak ada landasan kepercayaan antara penjual dan pembeli maka tidak akan terjadi transaksi dalam dunia ecommerce, apalagi mengetahui jika produk yang di jual dan di tawarkan oleh penjual merupakan produk yang semu, dalam artian produk yang dijual masih berupa bayangan penjual saja. Bagi konsumen online, melakukan transaksi dengan toko online akan mempertimbangkan ketidakpastian dan resiko jika dibandingkan dengan transaksi jual beli secara tradisional. Faktor keamanan transaksi masih menjadi kendala utama mengapa penetrasi transaksi online masih sangat kecil di Indonesia menurut Hasanuddin (2010). Untuk menjaga dan meningkatkan kepercayaan pelanggan, sebuah toko online harus bisa menjaga citra positif di mata para pelanggan. Citra ini dapat dibangun melalui kualitas produk pelayanan dan keamanan. Tanpa citra yang positif, kepercayaan yang sedang dan akan dibangun tidak akan terjaga [3].

\section{Kualitas Pelayanan}

\section{KAJIAN PUSTAKA}

Kualitas Pelayanan menurut Lovelock dalam Tjiptono (2011:58), mengemukakan bahwa kualitas pelayanan merupakan tingkatan kondisi baik buruknya sajian yang diberikan oleh penjual dalam rangka memuaskan konsumen dengan memberikan atau menyampaikan keinginan atau permintaan konsumen melebihi apa yang diharapkan konsumen.

Kepercayaan

Lau dan Lee (1999) mendefinisikan kepercayaan sebagai kesediaan individu untuk menggantungkan dirinya pada pihak lain dengan resiko tertentu. Kesediaan ini mencul karena adanya pemahaman individu tentang pihak lain yang didasarkan pada masa lalunya, adanya harapan piha lain akan memberikan sumbangan yang positif (walaupun ada juga kemungkinan pihak lain memberikan sumbangan yang negatif).

Keamanan

Kejahatan dalam media internet berjumlah sangat besar serta memiliki bentuk yang beragam karena beberapa alasan. Pertama, identitas individu, atau organisasi dalam dunia internet mudah untuk dipalsukan, tetapi sulit dibuktikan secara hukum (Jarvenpaa,1999). Kedua tidak membutuhkan sumber daya ekonomi yang besar untuk melakukan kejahatan dalam internet. Ketiga internet menyediakan akses yang luas pada pengguna yang potensial menjadi korban. Keempat kejahatan dalam internet, identitas pelaku tidak dikenal dan secara yuridis sulit mengejar pelaku.

Tindakan Pembelian Secara Online

Tindakan pembelian barang atau jasa dari mereka yang menjual barang atau jasa melalui internet di mana diantara penjual dan pembeli tidak melakukan kontak secara fisik yang dimana barang yang diperjual belikan ditawarkan melalui display dengan gambar yang di suatu website atau toko maya.

(https://www.hestanto.web.id/online-shop/)

Pengembangan Hipotesis

Kualitas pelayanan telah didefinisikan sebagai penilaian menyeluruh tentang keunggulan layanan yang disediakan oleh perusahaan. Efisiensi kualitas pelayanan digunakan untuk mengukur keunggulan dan ketepatan layanan yang diterima oleh pelanggan online. Kualitas pelayanan adalah faktor penting dalam bisnis secara umum, karena pelayanan yang baik pasti akan meningkatkan kepuasan pelanggan. Pembelian melalui internet sangat tergantung pada kualitas pelayanan yang diberikan oleh pihak penjual. Kualitas pelayanan yang prima akan membuat pembeli bersedia membeli barang atau jasa yang diperjualbelikan secara online.

H1 = Kualitas Pelayanan berpengaruh signifikan terhadap Tindakan Pembelian Produk Secara Online

Hanya pelanggan yang memiliki kepercayaan dan beranilah yang akan melakukan transaksi melalui media internet. Jika tidak ada landasan kepercayaan antara penjual dan pembeli maka tidak akan terjadi transaksi dalam dunia e-commerce.

$\mathrm{H} 2$ = Kepercayaan berpengaruh signifikan terhadap Tindakan Pembelian Produk Secara Online

Raman Arasu dan Viswanathan A. (2011), dalam Sukma (2011) melalui studi yang dilakukan pada 
konsumen online di Malaysia, menemukan bahwa faktor keamanan memiliki hubungan yang positif dan signifikan dalam mempengaruhi keputusan pembelian secara online. Dimana konsumen tidak akan melakukan pembelian tanpa adanya jaminan keamanan. Karena tanpa jaminan keamanan yang memadai tentunya akan menimbulkan kekhawatiran pada konsumen, yang pada akhirnya menghalangi mereka untuk melakukan pembelian. Dan sebaliknya ketika webstore mampu meningkat-kan keamanan dan memberikan jaminan kepada konsumennya maka keyakinan konsumen dalam berbelanja pun akan meningkat.

H3 = Keamanan berpengaruh signifikan terhadap Tindakan Pembelian Produk Secara Online

H4 =Kualitas pelayanan, kepercayaan dan keamanan berpengaruh secara simultan terhadap Tindakan Pembelian Produk Secara Online

\section{METODE PENELITIAN}

Populasi dan Sampel

Populasi dalam penelitian ini adalah semua orang yang pernah melakukan tindakan pembelian secara online. Teknik pengambilan sampel dalam penelitian ini menggunakan teknik purposive sampling yaitu menentukan pengambilan sampel dengan cara menetapkan ciri-ciri khusus yang sesuai dengan tujuan penelitian dengan serta menggunakan teknik convenience sampling yaitu pengambilan sampel didasarkan pada ketersediaan elemen dan kemudahan untuk mendapatkannya. Sampel dalam penelitian ini adalah konsumen berbagai produk sejumlah 100 orang yang memiliki kriteria tertentu yaitu:

a) responden yang pernah membeli produk melalui media internet minimal 1 kali

b) responden yang mudah ditemui dan memiliki waktu luang untuk mengisi kuesioner.

Sumber Data

Sumber data yang digunakan dalam penelitian ini merupakan Data Primer.Data Primer merupakan data yang diperoleh langsung dari responden, yang didapat dari jawaban responden atas kuesioner yang diberikan oleh peneliti. Kuesioner yang dibagikan secara langsung kepada responden menggunakan Skala Likert 5, yaitu :

1 = Sangat Tidak Setuju(STS)

$2=$ Tidak Setuju (TS)

$3=$ Cukup Setuju (CS)

$4=$ Setuju (S)

5 = Sangat Setuju (SS)

Data Sekunder adalah Data yang diperoleh secara tidak langsung melalui perantara (diperoleh dan dicatat oleh pihak tidak lain kemudian dipublikasikan) contohnya internet dan buku-buku teks yang menjadi acuan teoris dalam penelitian ini.

Metode Analisa Data

Hasil kuesioner yang didapatkan diuji menggunakan Uji Kualitas Data yaitu Uji Validitas dan Uji Reliabilitas, Uji Asumsi Klasik dan Pengujian Hipotesis menggunakan Uji Regresi Linear Berganda.

\section{HASIL DAN PEMBAHASAN}

Hasil uji regresi berganda sebagai berikut :

Tabel 1 : Regresi Berganda

\begin{tabular}{|c|c|c|c|c|c|c|c|c|}
\hline & \multirow[t]{2}{*}{ Model } & \multicolumn{2}{|c|}{$\begin{array}{c}\text { Unstandardized } \\
\text { Coefficients }\end{array}$} & \multirow{2}{*}{$\begin{array}{c}\begin{array}{c}\text { Standardized } \\
\text { Coefficients }\end{array} \\
\text { Beta }\end{array}$} & \multirow[t]{2}{*}{$t$} & \multirow[t]{2}{*}{ Sig. } & \multicolumn{2}{|c|}{$\begin{array}{c}\text { Collinearity } \\
\text { Statistics }\end{array}$} \\
\hline & & B & $\begin{array}{l}\text { Std. } \\
\text { Error }\end{array}$ & & & & Tolerance & VIF \\
\hline \multirow[t]{4}{*}{1} & (Constant) & 3.273 & 3.540 & & 2.723 & .035 & & \\
\hline & $\begin{array}{l}\text { Kualitas } \\
\text { layananX1 }\end{array}$ & .420 & .087 & .256 & 4.657 & .028 & . 056 & 0.007 \\
\hline & KeamananX2 & .487 & .154 & .613 & 6.628 & .025 & .041 & 0.045 \\
\hline & Kepercayaan X3 & 379 & .083 & .115 & 4.751 & .042 & .062 & 0.036 \\
\hline
\end{tabular}

a. Dependent Variable: TindakanPembelianOnlineY

Hasil persamaan regresinya adalah :

$\mathrm{Y}=0.256 X_{1}+0.613 X_{2}+0.115 X_{3}+\mathrm{e}$

Berdasarkan tabel diatas faktor Kualitas pelayanan, Keamanan dan Kepercayaan memiliki hubungan terhadap Tindakan Pembelian Produk Secara Online, maksudnya adalah semakin tinggi diatas faktor Kualitas layanan, Keamanan dan Kepercayaan terhadap Tindakan Pembelian Secara Online. Hubungan positif ini menunjukan bahwa faktor Kualitas layanan, Keamanan dan Kepercayaan memiliki pengaruh terhadap Tindakan Pembelian Produk Secara Online.

Uji R Square

Tabel di bawah ini akan menunjukan besarnya pengaruh faktor Kualitas pelayanan, Keamanan dan Kepercayaan memiliki pengaruh terhadap Tindakan Pembelian Produk Secara Online.

Tabel 2 : Model summary

\begin{tabular}{|c|c|c|c|c|}
\hline \multicolumn{5}{|c|}{ Model Summary $^{b}$} \\
\hline \multirow{2}{*}{$\frac{\text { Model }}{1}$} & R lare & \multirow{2}{*}{$\begin{array}{l}\begin{array}{l}\text { Adjusted R } \\
\text { Square }\end{array} \\
.851\end{array}$} & \multirow{2}{*}{$\begin{array}{l}\text { Std. Error of the } \\
\text { Estimate } \\
.51263\end{array}$} & \multirow{2}{*}{$\frac{\text { atson }}{1.657}$} \\
\hline & $769^{a} \quad .783$ & & & \\
\hline $\begin{array}{l}\text { ors: }(\mathrm{C} \\
\text { Keper }\end{array}$ & $\begin{array}{l}\text { nstant), } \mathrm{Ku} \\
\text { ayaanX3, }\end{array}$ & as layananX & eamananX2, & \\
\hline b. Dep & endent Varia & ole: Tindakan & mbelianOnlineY & \\
\hline
\end{tabular}

Angka tersebut mempunyai maksud bahwa pengaruh faktor Kualitas pelayanan, Keamanan dan Kepercayaan terhadap Tindakan Pembelian Secara Online adalah $78.30 \%$ dan sisanya sebesar $21.7 \%$ $(100 \%-78.30 \%)$ dipengaruhi oleh faktor lain. Untuk 
mengetahui model regresi di atas sudah benar atau salah, diperlukan uji hipotesis. Uji hipotesis menggunakan angka $\mathrm{F}$ sebagai mana tertera dalam tabel di bawah ini :

Tabel 3 : Uji F

\begin{tabular}{llrrrrr}
\hline \multicolumn{1}{l}{ Model } & $\begin{array}{l}\text { Sum of } \\
\text { Squares }\end{array}$ & \multicolumn{4}{c}{ df } & \multicolumn{2}{c}{ Square } & \multicolumn{1}{c}{ F } & Sig. \\
\hline 1 & Regression & 17.631 & 4 & 4.537 & 76.513 & $.000^{\mathrm{a}}$ \\
& Residual & 27.536 & 96 & .358 & & \\
& Total & 45.167 & 100 & & & \\
\hline
\end{tabular}

a. Predictors: (Constant), KualitaslayananX1, KeamananX2, KepercayaanX3,

b. Dependent Variable: Tindakan PembelianSecaraOnlineY

Dari hasil penghitungan, didapatkan angka $\mathrm{F}$ penelitian sebesar 76.513> F tabel sebesar 2.14 sehingga H0 ditolak H1 diterima. Artinya ada hubungan liner antara Kualitas layanan, Keamanan dan Kepercayaan secara bersama-sama berpengaruh terhadap tindakan pembelian secara online. Dengan demikian model regresi di atas sudah benar. Kesimpulanya adalah Kualitas pelayanan, Keamanan dan kepercayaan secara bersama-sama berpengaruh terhadap tindakan pembelian online. Besarnya pengaruh adalah $76.513 \%$.Berdasarkan perhitungan angka signifikan sebesar $0.000<0.05$ maka $\mathrm{H} 0$ ditolak dah H1 diterima. Artinya, ada hubungan linier antara Kualitas pelayanan , Keamanan dan kepercayaan secara bersama-sama berpengaruh terhadap tindakan pembelian secara online.

Tabel di bawah ini akan menjelaskan bagai mana pengaruh kualitas pelayanan, keamanan, dan kepercayaan secara parsial berpengaruh terhadap tindakan pembelian secara online.

Tabel 4 : Uji t

\begin{tabular}{|c|c|c|c|c|c|c|c|c|}
\hline \multirow[t]{2}{*}{ Mod } & & \multicolumn{2}{|c|}{$\begin{array}{c}\text { Unstandardized } \\
\text { Coefficieints }\end{array}$} & \multirow{2}{*}{$\begin{array}{c}\text { Standardized } \\
\text { Coefficients } \\
\text { Beta }\end{array}$} & \multirow[t]{2}{*}{$t$} & \multirow[t]{2}{*}{ Sig. } & \multicolumn{2}{|c|}{$\begin{array}{c}\text { Collinearity } \\
\text { Statistics }\end{array}$} \\
\hline & & B & $\begin{array}{l}\text { Std. } \\
\text { Error }\end{array}$ & & & & Tolerance & VIF \\
\hline \multirow[t]{4}{*}{1} & (Constar & 3.273 & 3.540 & & 2.723 & .035 & & \\
\hline & Kualita & .420 & .087 & .256 & 4.657 & .028 & .056 & 0.007 \\
\hline & Keam: & .487 & .154 & .613 & 6.628 & .025 & .041 & 0.045 \\
\hline & KepercayaanX3 & . 379 & . & .115 & 4.751 & .042 & .062 & 0.036 \\
\hline
\end{tabular}

a. Dependent Variable: TindakanPembelianOnlineY

Jadi berdasarkan perhitungan diperoleh angka t penelitian sebesar $4.657>\mathrm{t}$ tabel 1.6607. oleh karena itu maka H0 ditolak dan H1 diterima. Artinya ada hubungan linier antara Kualitas pelayanan dan Tindakan Pembelian secara online. Hasil penghitungan SPSS diperoleh angka $t$ sebesar 4.751. Jadi berdasarkan perhitungan diperoleh agka $\mathrm{t}$ penelitian sebesar $4.751<\mathrm{t}$ tabel 1.6607 . oleh karena itu maka HO ditolak dan H1 diterima. Artinya ada hubungan linier antara Kepercayaan dengan tindakan pembelian secara online.

Tabel 5 Uji Multikolineritas

\begin{tabular}{|c|c|c|c|c|c|c|c|c|}
\hline \multirow[t]{2}{*}{$\overline{\mathrm{Mo}}$} & & \multicolumn{2}{|c|}{$\begin{array}{c}\text { Unstandardized } \\
\text { Coefficients }\end{array}$} & $\begin{array}{l}\text { Standardized } \\
\text { Coefficients }\end{array}$ & \multirow[t]{2}{*}{$\mathrm{t}$} & \multirow[t]{2}{*}{$\begin{array}{l}\text { Sig. } \\
\text { S }\end{array}$} & \multicolumn{2}{|c|}{$\begin{array}{l}\text { Collinearity } \\
\text { Statistics }\end{array}$} \\
\hline & & B & $\begin{array}{l}\text { Std. } \\
\text { Error }\end{array}$ & Beta & & & Tolerance & $\mathrm{VIF}$ \\
\hline \multirow[t]{4}{*}{1} & (Constant) & 3.273 & 3.540 & & 2.723 & .035 & & \\
\hline & Kualitas PX1 & .420 & .087 & .256 & 4.657 & .028 & .056 & 0.007 \\
\hline & KeamananX2 & .487 & .154 & .613 & 6.628 & .025 & .041 & 0.045 \\
\hline & KepercayaanX3 & .379 & .083 & .115 & 4.751 & .042 & .062 & 0.036 \\
\hline
\end{tabular}

a. Dependent Variable: TindakanPembelianOnlineY

Untuk melihat gejala multikolineritas, kita dapat melihat dari hasil tabel statistik kolineritas. Hasil VIF yang lebih besar dari satu menunjukan adanya gejala multikolineritas. Dari hasil output tersebut terlihat bahwa nilai VIF tidak ada yang lebih dari 10. jadi dapat disimpulkan bahwa tidak tejadi multikolineritas antar variabel independen dalam model regresi. Dari hasil perhitungan nilai tolerance juga menunjukan tidak ada variabel independen yang memiliki nilai tolerance kurang dari 0.1 yang berati tidak ada korelasi antara variabel independen.

\section{6: Hasil Korelasi}

\begin{tabular}{llrrr}
\hline & & KualitasPX1 & KeamananX2 & KepercayaanX3 \\
\hline KualitasPX1 & Pearson & 1 & $.375^{* *}$ & $.479^{* *}$ \\
& Correlation & & .000 & .000 \\
& Sig. (1-tailed) & 100 & 100 & 100 \\
& $\mathrm{~N}$ & $.375^{* *}$ & 1 & $.482^{*}$ \\
KeamananX2 & & & .000 \\
& Pearson & .000 & & 100 \\
& Correlation & 100 & 100 & 1 \\
& Sig. (1-tailed) & $.479^{* *}$ & $.482^{* *}$ & \\
KepercayaanX3 & $\mathrm{N}$ & & .000 & 100 \\
& Pearson & .000 & 100 & \\
& Correlation & 100 & & \\
& Sig. (1-tailed) & $\mathrm{N}$ & & \\
& **. Correlation is significant at the 0.01 level (1-tailed). & &
\end{tabular}

Dari sekian banyak data diatas yang mempunyai hubungan korelasi cukup kuat sebagai berikut :

1.Keamanan dengan Kepercayaan sebesar 0.482

2.Kualitas dengan Kepercayaan 0.479

3.Keamanan dengan Kualitas sebesar 0.375

Dan faktor yang lainnya tidak mempunyai hubungan korelasi yang kuat atau dapat dikatakan sangat lemah.

\section{Gambar 1 : Uji Heterokedastisitas}

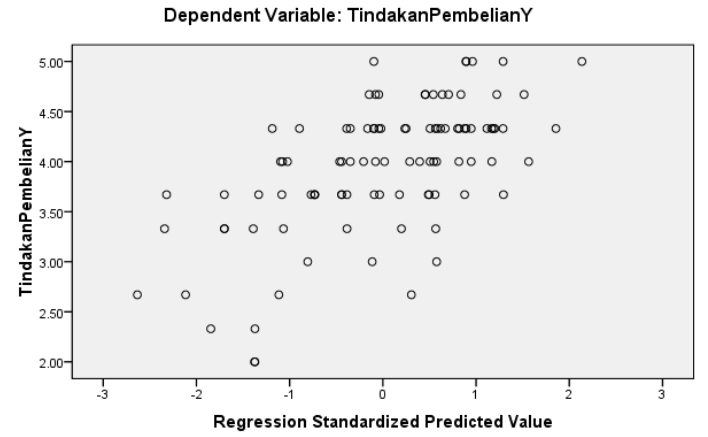


Dari hasil tersebut terlihat bahwa penyebaran residual adalah tidak teratur. Hal tersebut dapat dilihat dari plot yang terpencar dan tidak membentuk pola tertentu. Dengan hasil demikian, kesimpulan yang bias diambil adalah bahwa terjadi gejala homokedastisitas maka heterokedastisitas tidak terjadi

\section{Gambar 2 : Uji Normalitas}

\section{Normal P-P Plot of Regression Standardized Residual}

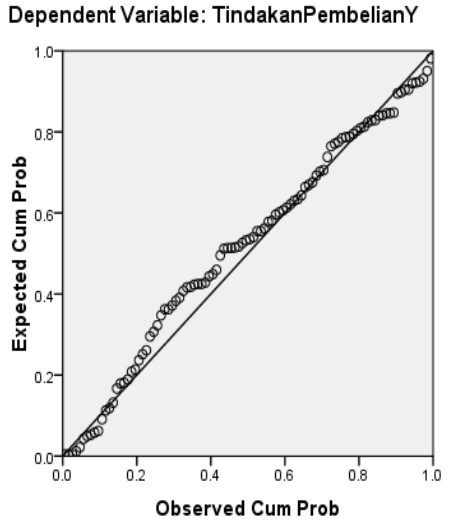

Untuk melihat apakah data terdistribusi normal atau tidak kita dapat melihat dari grafik histogram. Dari grafik output kita bisa melihat bahwa grafik niat bertransaksi mengikuti bentuk distribusi normal dengan bentuk histogram, kita bisa melihat juga melalui P-Plots, suatu data akan terdistribusi normal jika nilai probabilitas yang di harapkan adalah sama dengan nilai probabilitas pengamatan. Pada grafik PPlots, kesamaan antara nilai probabilitas harapan dan probabilitas pengamatan ditunjukan dengan garis diagonal yang merupakan perpotongan antara garis probabilitas harapan dan probabilitas pengamatan. Dari grafik terlihat bahwa nilai P-Plots terletak diantara garis diagonal. Jika kita lihat lebih jauh terlihat bahwa nilai P-Plots tidak menyimpang jauh dari garis diagonal, sehingga bisa diartikan bahwa data ini adalah normal.

\section{PEMBAHASAN HASIL}

Dari ke tiga faktor semua memiliki mempunyai pengaruh yang signifikan terhadap tindakan pembelian produk secara online yaitu faktor Keamanan sebesar $61.3 \%$, Keamanan sebesar 25.6\%, dan Kualitas Pelayanan $11.5 \%$. Hasil analisa menggunakan Uji F Dari pengujian menggunakan uji f didapatkan angka 76.513\%. Angka tersebut mempunyai maksud bahwa pengaruh Keamanan, Kepercayaan dan Kualitas
Pelayanan terhadap Niat bertansaksi secara online adalah $76.513 \%$ dan sisanya sebesar $23.487 \%$ (100\% $76.5132 \%$ ) dipengaruhi oleh faktor lain. Hasil analisa menggunakan Uji Multikolineritas. Dari hasil output tersebut terlihat bahwa nilai VIF adalah tidak ada yang lebih dari 10 Kesimpulan yang bisa diperoleh adalah bahwa model regresi di atas tidak terjadi multikolineritas. Hasil analisa menggunakan Uji Heterokedastisitas Dari hasil tersebut terlihat bahwa penyebaran residual adalah tidak teratur. Hal tersebut dapat dilihat dari plot yang terpencar dan tidak membentuk pola tertentu. Dengan hasil demikian, kesimpulan yang bisa diambil adalah bahwa tidak terjadi gejala homokedastisitas atau persamaan regresi memenuhi asumsi heterokedastisitas. Hasil analisa menggunakan Uji Normalitas Dari grafik terlihat bahwa nilai P-Plots terletak diantara garis diagonal. Jika kita lihat lebih jauh terlihat bahwa nilai P-Plots tidak menyimpang jauh dari garis diagonal, sehingga bisa diartikan bahwa data ini adalah normal.

\section{KESIMPULAN DAN SARAN}

\section{Kesimpulan}

Faktor Keamanan, Kepercayaan, dan Kualitas layanan secara bersama-sama mempunyai pengaruh yang signifikan terhadap Tindakan Pembelian secara online. Dari penghitungan menggunakan Uji t atau secara parsial dapat disimpulkan bahwa dari ke tiga faktor Keamanan, Kepercayaan, dan Kualitas layanan semuanya yang mempunyai pengaruh yang signifikan terhadap Tindakan Pembelian secara online. Dari ke tiga faktor tersebut faktor Keamanan yang dominan pengaruhnya terhadap Tindakan Pembelian secara online.

Saran

Keamanan adalah faktor yang berpengaruh signifikan yang pertama. Hendaknya perusahaan yang memasarkan produknya melalui media sosial memperhatikan faktor keamanan ini misalnya selalu memastikan apakah pembeli sudah menerima barang yang dibeli, menjaga keamanan akun sehingga tidak mudah diretas orang yang tidak bertanggung jawab, memberikan garansi akan keutuhan barang saat diterima pembeli. Jika pembeli merasa aman berbelanja di perusahaan tersebut secara online maka dia akan memberitahukan kepada teman dan saudaranya untuk berbelanja di tempat yang sama. Kepercayaan adalah yang berpengaruh faktor signifikan kedua Setelah calon pembeli merasa aman terhadap sebuah perusahaan yang memasarkan secara online dengan mendengar atau mendapat rekomendasi dari teman dan saudara yang pernah membeli di tempat 
tersebut maka akan timbul rasa percaya terhadap perusahaan tersebut. Perusahaan perlu menyusun program yang merespon secara aktif tanggapan, keluhan pembelinya. Respon yang cepat membuat pembeli merasa aman dan percaya sehingga meningkatkan keinginan mereka untuk melakukan transaksi secara online.

\section{REFERENSI}

[1] E. N. Mahmudah and R. Nuryuniarti, "Analisis Tingkat Kepuasan Mahasiswa terhadap Kualitas Pelayanan Universitas Muhammadiyah Tasikmalaya," Bus. Innov. Entrep. J., vol. 1, no. 3, pp. 158-165, 2019, doi: 10.35899/biej.v1i3.68.

[2] Q. Zaman, "Mediating Effect of Perceived Organizational Support on the Relationship between Leader-Member Exchange and the Innovation Work Behavior of Nursing Employees: A Social Exchange Perspective Wings to the Research Volume 4-Issue-3," COJ Nurs. Healthc., vol. 4, no. 3, pp. 68-77, 2018, doi: 10.31031/COJNH.2018.04.000592.

[3] A. Solihat, H. F. Tampubolon, R. Rahmayani, and A. Trijumansyah, "Analisis Kepercayaan dan Kualitas Situs pada Minat Beli Produk ECommerce Bukalapak," Bus. Innov. Entrep. J., vol. 1, no. 2, pp. 72-81, 2019, doi: 10.35899/biej.v1i2.55.

[4] Hausman, A.V., dan Siekpe, Sam, J. 2009. 'The effect of web interface features on consumer online purchase intentions'. Journal of Business Research, Vol 62 pp.5-13.

[5] Jarvenpaa, Sirkka L., Noam Tractinsky, and Michael Vitale. (2000). Consumer trust in an Internet store. InformationTechnology and Management 1, pp.45-71.
[6] Lau, Geok Then and Sook Han Lee. 1999. "Consumers Trust in a Brand and the Link to Brand Loyalty". Journal of Market Focused Management.

[7] LaQuey, T. 1997.Internet Companion: A Beginner's Guide to Global Networking. Wospakrik, Hans J. (penerjemah). Sahabat Internet: Pedoman bagi pemula untuk memasuki jaringan global. Bandung: Penerbit ITB.

[8] Muhammad Syaifudin , 2014, Analisis Pengaruh Privasi, Keamanan dan Kepercayaan Terhadap Niat Untuk Bertransaksi Secara Online di OLX.CO.ID Jurnal Manajemen Pemasaran, FEB Universitas Brawijaya

[9] Nazar, M. Rafki dan Syahran,2008. Pengaruh Privasi, Keamanan, Kepercayaan, Dan Pengalaman Terhadap Niat Untuk Bertransaksi Secara Online. Simposium Nasional Akuntansi 11. Pontianak, 22-25 Juli 2008.

[10] Raman, Arasu., dan Viswanathan, A. 2011. Web Services and e-Shopping Decisions: A Study on Malaysian e-Consumer. IJCA Special Issue on:Wireless Information Networks \& Business Information System, hal.54-60.

[11] Rosalina. 2013. 'E-commerce Dorong Fungsi Media Sosial untuk Jualan'. 03 Juli, Diakses 06 Oktober 2015. http:// www.tempo.co/read/news/2013/07/03/072493 322/ Ecommerce- Dorong-Fungsi-MediaSosial-untuk- Jualan.

[12] Sulianta, F. 2012. Smart Online Marketer. Edisi Pertama. Yogyakarta: Penerbit Andi.

[13] Tjiptono, Fandy, dan Chandra, Gregorius. 2005. Service, Quality, and Satisfaction. Penerbit Andi, Yogyakarta

[14] Wahyudi, R.dkk 2012, Pengaruh Kualitas Sistem, Informasi dan Pelayanan SIAKAD Terhadap Kepuasan Mahasiswa (Studi Pada Mahasiswa Program Sarjana Fakultas Ilmu Administrasi, Universitas Brawijaya). 